\title{
Privatization in Developing Countries: A Promising Development Strategy?
}

\section{Illmiawan Auwalin}

Faculty of Economics and Business, Universitas Airlangga

\section{Abstract}

This paper analyses privatization as one of development strategies in developing countries. In the last two decades, there has been an increasing trend of privatizing state owned enterprises (SOE) in developing countries. This paper clarifies that the process to decide the implementation of privatization in a developing country is a complex issue. The decision to privatize is not merely weighing the potential benefits of privatization, but also requires consideration of the circumstances of the country itself. The prerequisite circumstances of privatization in developing countries, including macroeconomic stability, the large role of the private sector, and low corruption level, will be discussed.

Corresponding Author:

IImiawan Auwalin

auwalin@feb.unair.ac.id

Received: 10 February 2019 Accepted: 14 March 2019 Published: 28 March 2019

Publishing services provided by Knowledge E

(c) Ilmiawan Auwalin. This article is distributed under the terms of the Creative Commons

Attribution License, which permits unrestricted use and redistribution provided that the original author and source are credited.

Selection and Peer-review under the responsibility of the ICIEBP Conference Committee.
G OPEN ACCESS
Privatization has been one of the major development strategies both in the developed and developing countries in the last two decades of the twentieth century. For the purpose of privatization, more than 100 governments in the world have sold their shares in state owned enterprises (SOE) to private sectors and gained U.S.\$1 trillion in revenue as a result (Megginson 2000, p. 14). Privatization is also one of the most important development policies continuously prescribed to developing countries by international agencies such as the World Bank and International Monetary Fund (IMF). The developing countries in Asia, Africa, Latin America and placeEastern Europe have been actively implementing privatization programs shown by the leaping number of privatization transactions in the early 90s. In the periods 1980-87 and 1988-93, privatization transactions in developing countries increased 400 percent from 456 to 2,279 (World Bank 1995, p. 27). The increasing trend confirms that privatization is an important issue in development, especially in developing countries.

This paper clarifies that the process to decide the implementation of privatization in a developing country is a complex issue. Though privatization may offer various prospective benefits, including reduced fiscal deficit, possibly lower prices of good and services, and higher economic growth (World Bank, 1995, p. 257), the decision to privatize is not merely weighing the potential benefits of privatization, but also requires consideration of the circumstances of the country itself. The required circumstances would likely make 
privatization in a developing country as a long term gradual process. The prerequisite circumstances for privatization might include the economic and political conditions of a developing country, however this paper will only discuss the economic issue. The required economic conditions for successful privatization in developing countries could include stable macroeconomic conditions, the significant role of private sectors, and the absence of corruption. In addition to these three prerequisite conditions, credible and effective regulation is another important consideration. However, regulation issue would be closely related with political economy topic.

Macroeconomic stability is an important consideration prior to any privatization decision in developing countries. Privatization under unstable macroeconomic conditions would tend to result in low revenue without any beneficial impact on economic recovery. In an economic crisis, the pressure to cover a budget deficit often reduces a government's bargaining power and the government might end up selling SOE at a low price (Smith and Trebilcock 2001, p. 234). Consequently, both an economic recovery program and a privatization program in developing countries would be less effective when implemented at the same time. A study of 35 developing countries shows that privatization policy is mostly based on the need to resolve economic crises, rather than clear consideration for long term development goals (Banerjee and Munger 2004, p. 213). The result of the study might be the explanation for why privatization programs in many developing countries do not help much in the economic crisis recovery. Therefore, privatization in developing countries would possibly be more beneficial when the privatization is decided and implemented under stable macroeconomic condition.

The significant role of private sectors is another essential prerequisite condition for privatization. One of the indications of significant private sectors' contribution on an economy is the existence of a competitive market. Privatization within an economy which lacks competition would result in adverse effects including higher prices because of monopolies, the lack of any efficiency improvements on the privatized SOEs, and less domestic investor participation during privatization (Smith and Trebilcock 2001, p. 234). These three negative effects are more likely to occur in the privatization program of developing countries as most countries have poor market competition and a reasonably small role of the private sector in the economy. In fact, in many developing countries, the governments still hold the main role in the economy, especially in provision of public goods and services along with employment creation (ADB, 1985: 259). In these countries, the decision to privatize would possibly require prior efforts from the government in fostering private sector development in order to enlarge the private sector role in the economy. 
Minimum levels of corruption are also a fundamental prerequisite for successful privatization. Corruption could obviously lead to poor credibility of the privatization program, low revenues from privatization, and a reduction of the potential long term benefits of privatization. High levels of corruption in certain countries could lower the credibility of the privatization program as the investors may assume that the privatization process in the country lacks transparency and accountability (Banerjee and Munger 2004 , p. 213). Transparent and accountable processes are widely considered as an effort to minimize corruption. Furthermore, privatization would not result in actual potential revenue with the presence of corruption. In a corrupt environment, the privatization decision maker would possibly base the decision on personal financial benefit rather than larger benefit consideration (Smith and Trebilcock 2001, p. 235). When such personal interests influence decision making process, the best possible price of the SOE will probably not be included as a consideration. In addition, larger and longer potential benefits of privatization in the form of increasing investment, especially foreign direct investment, would also likely be reduced by corruption (Smith and Trebilcock 2001, p. 235). Foreign investment is one of the important sources for economic development in developing countries. Considering the costs of corruption on privatization, minimizing corruption is probably an important effort by developing countries prior to deciding to sell their SOEs.

In summary, while privatization proposes many potential benefits for developing countries, the prerequisite circumstances prior to the decision to privatize need to be carefully considered. Privatization will be less effective when developing countries decide to privatize their SOE under macroeconomic instability, minimum private sectors contribution, and high intensity of corruption. On the contrary, deciding on privatization in a developing country by realizing the prerequisite conditions would be more effective in terms of implementation and in achieving the benefit of privatization. Therefore, the economic prerequisites are important in order to obtain the most of privatization as a development strategy in developing countries. Consequently, the process of setting up the prerequisite requirements would likely make privatization a gradual process in development countries.

\section{References}

[1] Asian Development Bank 1985, An International Parley on 'Privatization', American Journal of Economics and Sociology, vol. 44, no. 3, pp. 257-260, viewed 4 July 2007, <http://www.jstor.org/journals/00029246.html> 
[2] Banerjee, SG \& Munger, MC 2004, 'Move to Markets? An Empirical Analysis of Privatization in Developing Countries', Journal of International Development, no. 16, pp. 213-240, viewed 5 July 2007, <http://www3.interscience.wiley.com/cgi-in/ jhome/5102>

[3] Megginson, W 2000, 'Privatization', Foreign Policy, no. 118, Spring, pp. 14-27, viewed 6 July 2007, <http://www.jstor.org/journals/00157228.html>

[4] Smith, DAC \& Trebilcock, MJ 2001, 'State-Owned Enterprises in Less Developed Countries: Privatization and Alternative Reform Strategies', European Journal of Law and Economics, no.12, pg. 217-252, viewed 6 July 2007, <http://www.springerlink. com/content/100264/>

[5] World Bank 1995, Bureaucrats in Business: The Economics and Politics of Government Ownership, New York: Oxford University Press. 